\title{
Treatment Strategy for Perianal Fistulas in Crohn Disease Patients: The Surgeon's Point of View
}

\author{
Jong Lyul Lee, Yong Sik Yoon, Chang Sik Yu \\ Department of Surgery, Asan Medical Center, University of Ulsan College of Medicine, Seoul, Korea
}

Perianal fistula is a frequent complication and one of the subclassifications of Crohn disease (CD). It is the most commonly observed symptomatic condition by colorectal surgeons. Accurately classifying a perianal fistula is the initial step in its management in CD patients. Surgical management is selected based on the type of perianal fistula and the presence of rectal inflammation; it includes fistulotomy, fistulectomy, seton procedure, fistula plug insertion, video-assisted ablation of the fistulous tract, stem cell therapy, and proctectomy with stoma creation. Perianal fistulas are also managed medically, such as antibiotics, immunomodulators, and biologics including anti-tumor necrosis factor-alpha agents. The current standard treatment of choice for perianal fistula in CD patients is the multidisciplinary approach combining surgical and medical management; however, the rate of long-term remission is low and is reported to be $50 \%$ at most. Therefore, the optimum management strategy for perianal fistulas associated with CD remains controversial. Currently, the goal of management for CD-related perianal fistulas are controlling symptoms and maintaining long-term anal function without proctectomy, while monitoring progression to anorectal carcinoma. This review evaluates perianal fistula in CD patients and determines the optimal surgical management strategy based on recent evidence.

\section{Keywords: Crohn disease; Inflammatory bowel disease; Anal fistula}

\section{INTRODUCTION}

Perianal fistula is an abnormal connection between the anorectum and perianal epithelium [1]. Perianal fistulas are frequently observed in Crohn disease (CD) patients and are the most common symptom in CD patients seen by colorectal surgeons [2]. Presence of anorectal stricture, male, perianal abscess, and rectal inflammation are associated with perianal fistula related to $\mathrm{CD}$ [3]. The cumulative incidence of perianal fistulas among CD patients in the US is approximately $10 \%$ at 1 year after diagnosis, $15 \%$ at 5 years, $18 \%$ at 10 years, $23 \%$ at 20 years, and $24 \%$ at 30 years $[2,4]$. The overall prevalence of perianal fistulas in Europe,

Received: Jan 29, 2021 Revised: Feb 8, 2021 - Accepted: Feb 8, 2021 Correspondence to: Chang Sik Yu, M.D.

Department of Surgery, Asan Medical Center, University of Ulsan College of Medicine, 88 Olympic-ro 43-gil, Songpa-gu, Seoul 05505, Korea

Tel: +82-2-3010-3494, Fax: +82-2-474-9027

E-mail: csyu@amc.seoul.kr

ORCID: https://orcid.org/0000-0001-9401-9981

(c) 2021 The Korean Society of Coloproctology

This is an open-access article distributed under the terms of the Creative Commons Attribution NonCommercial License (https://creativecommons.org/licenses/by-nc/4.0) which permits unrestricted noncommercial use, distribution, and reproduction in any medium, provided the original work is properly cited. estimated as the sum of the estimated prevalence for all etiologies, was $1.69 / 10,000$ population [5]. In a multicenter study in Korea, $35 \%$ of CD patients had a history of perianal fistula, while $28 \%$ had concomitant perianal fistulas at the time of the $\mathrm{CD}$ diagnosis $[6,7]$.

In the Montreal revision of the Vienna classification, the 3 predominant parameters of age at diagnosis, location, and behavior were not changed, but perianal disease alone required separate subclassification [8]. There are substantial data that perianal disease is not necessarily associated with intestinal fistulizing disease [9]. Although perianal fistula is not associated with the locationbased classification, the risk of perianal fistulas is up to $92 \%$ higher in those with colonic disease with rectal involvement [2].

The presence of perianal fistula negatively affects a patient's quality of life due to the occurrence of pain, perianal discharge, and the impairment of both physical and sexual functions [10]. The treatment goal of perianal fistula in $\mathrm{CD}$ is the resolution of the perianal fistula, improvement of quality of life, maintenance of fecal continence, and avoidance of proctectomy with stoma creation [11].

Currently, the best approach to achieve the resolution of perianal fistula is a combination of medical and surgical management, 
resulting in fistula healing in $50 \%$ of patients $[10,12]$. The improvement in biologics and management strategy, i.e., top-down treatment, have led to a rise in the rate of complete remission in the treatment of $\mathrm{CD}$, but the rate of perianal fistula healing remains low [13]. Recent reviews are mainly related to medical treatment, but the effectiveness of new biologic agents requires further evaluation.

The aim of the current review was to demonstrate the evidence regarding surgical treatment of perianal fistulas in $\mathrm{CD}$ patients and to discuss in detail multidisciplinary surgical treatment strategy.

\section{CLASSIFICATION, OUTCOME EVALUATION, PROGNOSTIC FACTORS}

\section{Classification of perianal fistulas in Crohn disease patients}

Surgical treatment of perianal fistula can vary from simple abscess drainage to a surgical approach depending on the type and the extent of the fistula. Therefore, anatomical description with appropriate classification of the perianal fistula is crucial before starting any kind of management (medical or surgical). The anatomical description of fistulas should include the type of fistula, location of internal and external openings, and the presence of secondary branches and abscesses. There are several classifications of perianal fistulas, from the oldest Goligher classification to the recent American Gastroenterological Association (AGA) classification. A clinically useful classification of perianal fistulas in $\mathrm{CD}$ should enable the physicians to determine the optimal management strategy; however, there is no consensus regarding which classification system should be used. Therefore, many studies classify the type of anal fistula in CD patients as 'mixed.' The current review analyzes the types of perianal fistula in $\mathrm{CD}$ patients, a factor contributing to the selection of the management strategy.

The traditional classifications include those proposed by Goligher (1875), Milligan-Morgan (1934), Parks (1976), and Eisenhammer (1978), especially for horseshoe fistula [14]. The traditional classification widely used to date is the Parks classification, which was a result of an analysis of 400 patients [15] and provided a detailed description of the course of the perianal fistulous tract in relation to the external and the levator ani muscle. However, this classification does not provide any information regarding the complexity of the fistula (secondary tracts or the presence of abscess) or the presence of proctitis [3]. The Parks classification is considered to determine the type of usual perianal fistula, but perianal fistula arising from $\mathrm{CD}$ is more complicated. The AGA classification (2003) proposed that perianal fistulas should be divided into 2 categories based on fistula tract anatomy, the number of external openings, and presence of abscess and/or proctitis; simple or complex [16]. This classification has prognostic relevance for fistula healing as patients with more complex fistula are less likely to achieve clinical remission than patients with simple fistulas [17]. However, the "complex fistula" category is based on multiple variables and does not permit proper individualization of treatment [3]. The St. James University Hospital (SJUH) classification (1996) [18, 19], based on magnetic resonance image (MRI) findings, has 5 grades based on detailed information on the primary fistulous tract, its relation to the sphincter, and on secondary tracts and related abscess [19]. This classification enables objective preoperative assessment for the colorectal surgeon and is more predictive of surgical outcome than preoperative or intraoperative classification [20]. However, this classification is not simple to apply in daily clinical practice. The Hughes-Cardiff classification (1978) [21], which is less commonly used, divided fistulas into simple and complex categories and had advantages in terms of prognostic value but lacks information on anatomical description (Table 1).

\section{How to determine the remission status and drainage status of perianal fistulas?}

To describe the outcomes, the remission status needs to be defined. Complete remission is defined as symptomatic and radiographic remission; symptomatic remission, the absence of both pain and drainage from the fistula tract; and radiographic remission, the absence of inflammation in any fistula tract and the absence of any abscess based on the Toronto consensus [22]. Furthermore, symptomatic response is defined as meaningful improvement in the symptoms of pain and drainage as judged by both the patient and physician in the absence of remission; this response should not be considered a desirable final outcome but is useful to assess early response to treatments [22]. From the radiologic point of view, deep remission is defined as the presence of clinical remission and the abscess of anal canal ulcers and fistula healing on MRI [23]. The timing of evaluation of remission or response is reported differently for each study results from 8 weeks to 12 months [22, 24-26].

To evaluate the efficacy of management, a clinical trial used a simple fistula drainage assessment that defined "closure" when a fistula no longer showed drainage despite gentle finger compression; "response," a reduction of $50 \%$ or more in the number of draining fistulas on at least 2 consecutive visits; and "remission," the absence of any draining fistulas on 2 consecutive visits [27]. The "gentle finger compression" approach is largely investigator dependent and has never been formally validated [28]. The presence of a persistent tract without fluid drainage is defined as "remission." The external appearance of the fistula is used as a surrogate for the whole internal fistula tract [28]. MRI studies have shown that internal fistula healing lags behind clinical remission by a median of 12 months.

\section{Prognostic factors for recurrence and poor healing}

Understanding the risk factors for recurrence helps colorectal surgeons and patients in the optimal management of a perianal fistula in the context of CD. Generally, perianal fistulas healed better and the recurrence rate was lower in patients without rectal in- 
Table 1. Classification of type of perianal fistula

\begin{tabular}{|c|c|c|c|c|c|}
\hline \multirow{2}{*}{ Variable } & \multicolumn{5}{|c|}{ Classification } \\
\hline & Parks & AGA & St James University Hospital & Hughes-Cardiff & Milligan-Morgan \\
\hline \multirow{4}{*}{$\begin{array}{l}\text { Type of } \\
\text { perianal } \\
\text { fistula }\end{array}$} & Intersphincteric (70\%) & Simple: low, single & Imaging-based & Ulceration $(\mathrm{U} 0,1,2)$ & Subcutaneous (5\%) \\
\hline & Suprasphincteric (4\%) & & $\begin{array}{l}\text { Grade } 2 \text {, grade } 1 \text { with } \\
\text { abscess or additional fistula }\end{array}$ & Stricture $(\mathrm{S} 0,1,2)$ & High anal (8\%) \\
\hline & & & $\begin{array}{l}\text { Grade } 4 \text {, grade } 4 \text { with } \\
\text { abscess or additional fistula }\end{array}$ & Proximal bowel involvement $(P)$ & Submucous (5\%) \\
\hline & & & $\begin{array}{l}\text { Grade 5, supra-levator or } \\
\text { trans-levator }\end{array}$ & Disease activity (D) & \\
\hline \multirow[t]{2}{*}{ Pros } & $\begin{array}{l}\text { Detailed description of fistula } \\
\text { course }\end{array}$ & Simple & $\begin{array}{l}\text { Objective preoperative } \\
\text { assessment }\end{array}$ & Easily stored registry & $\begin{array}{l}\text { Detailed description of fistula } \\
\text { course }\end{array}$ \\
\hline & & & & Provide prognostic information & \\
\hline \multirow[t]{2}{*}{ Cons } & $\begin{array}{l}\text { No information of complexity } \\
\text { and presence of proctitis }\end{array}$ & $\begin{array}{l}\text { No individualization of } \\
\text { treatment }\end{array}$ & $\begin{array}{l}\text { Difficult to use of daily } \\
\text { practice }\end{array}$ & Need proficiency & $\begin{array}{l}\text { No information of complexity } \\
\text { and presence of proctitis }\end{array}$ \\
\hline & & $\begin{array}{l}\text { Different treatment among } \\
\text { the complex types }\end{array}$ & & Lack of cutoff value & \\
\hline
\end{tabular}

AGA, American Gastroenterological Association; RVF, rectovaginal fistula.

volvement than in those with rectal involvement [29]. It has been reported that the need for proctectomy is significantly higher in patients with rectal involvement $[25,30,31]$. Therefore, rectal involvement of $\mathrm{CD}$ is considered a poor prognostic factor. Besides, the complex type of perianal fistulas also showed lower remission rates and higher recurrence rates; it can be considered a prognostic factor [29, 31-33]. However, since the definition of a complex fistula was slightly different in each study, it is necessary to properly define it in the future.

A meta-analysis using the data from 6,168 patients (20 eligible studies) reported risk factors for anal fistula recurrence, divided into patient-related factors and surgery-related factors [34]. The pooled recurrence rate from this meta-analysis was $19 \%$, which ranged from $2.5 \%$ to $57.1 \%$ [34]. Prior anal surgery showed a significant association with anal fistula recurrence and surgery in terms of patient-related factors [34]. Although smoking was previously known as a risk factor for recurrence $[35,36]$, this metaanalysis reported that there was no correlation between smoking and recurrence [34]. Besides, in terms of poor healing, rectovaginal fistula and the nucleotide-binding oligomerization domain 2 (NOD2) variant were related to a lower probability of complete remission and a longer time to complete fistula closure [37-39]. In clinical practice, NOD2, the first CD gene identified, represents the strongest genetic predictor of CD susceptibility and phenotype and the NOD2 variant is strongly associated with the development of perianal fistulas [38]. In the era of biologic treatment, the presence of CD granulomas in the perineum reduced the chance of healing or improvement of a perianal fistula [40].

In terms of surgery-related factors, a high transsphincteric fistula, an unidentified internal opening, horseshoe extension, and multiple fistulas were significantly associated with recurrence after surgery [34, 41-46]. In a meta-analysis regarding surgery, there was a significant difference in recurrence prognostic between seton procedure and fistulotomy (relative risk, 2.97; 95\% confidence interval, 1.43-2.59), but recurrence prognosis was not different between fistulotomy and fistulectomy and between use of endorectal mucosal advancement flap (EMAF) and fistulotomy [34, $41,42,47,48]$.

\section{MANAGEMENT STRATEGY}

Colorectal surgeons should carefully examine the perianal fistula and review the preoperative imaging, such as 3-dimensional endorectal ultrasound (EUS), computed tomography (CT), and MRI images, to understand the anatomy of the perianal fistula and obtain exact prognostic information. Prior anal surgery is a poor prognostic factor for recurrence $[34,45]$; therefore, the first surgery is the best chance to obtain complete remission. The decision to perform surgical treatment for perianal fistulas in CD patients must be individualized and based on the extent of disease and severity of symptoms. Despite the best available medical and surgical management strategies, perianal fistula in CD patients 
have a poor prognosis and may result in the need for proctectomy or permanent diversion in some patients with severe perianal fistula [49-54]. A consensus described the goals of treating perianal fistulas, with the short-term goals as abscess drainage and reduction in symptom severity and the long-term goals as the resolution of fistula discharge, improvement in quality of life, fistula healing, resolution of fecal incontinence, and avoiding proctectomy with stoma creation [11]. Therefore, the current review discusses management strategy based on the presence of symptoms, extent of disease, and management goals.

\section{Simple, asymptomatic perianal fistula without rectal involvement of Crohn disease}

There have been few studies or recommendations about simple, asymptomatic perianal fistulas related to CD. The American Society of Colon and Rectal Surgeon (ASCRS) recommends that patients with asymptomatic anal fistulas which are accidentally discovered with no signs of local sepsis require no surgical intervention [55]. The second Korean guidelines for the management of $\mathrm{CD}$ also recommended that this type of perianal fistulas do not require treatment [56]. These fistulas may remain indolent for an extended period of time; therefore, patients need not be subjected to the morbidity of operative intervention (Table $2[3,10,22,54$ -
56]). Considering that antibiotics improve fistula symptoms but do not induce fistula closure $[57,58]$, these patients do not need antibiotic therapy. Even if no management is required for this type of perianal fistula, exam under anesthesia (EUA) by colorectal surgeon; imaging studies including EUS, CT, or MRI; and endoscopy to evaluate the rectal involvement in the presence of $\mathrm{CD}$ are needed to ensure accurate fistula diagnosis and classification.

\section{Simple, symptomatic perianal fistula without rectal involvement of Crohn disease}

Surgical or medical treatment should be considered for simple, symptomatic perianal fistulas in CD patients $[55,56]$. A natural history study found that more than $70 \%$ of patients achieved complete remission after undergoing medical or surgical treatment [32]. If the patients developed superficial or ischiorectal abscesses, these abscesses should be drained externally by incision and drainage for relieving symptoms, followed by EUA $[59,60]$. Antibiotics, most commonly ciprofloxacin and metronidazole, are considered the first-line treatment for this type of fistula. Evidence on the use of antibiotics is limited and comes from small case series. Studies on metronidazole or comparing the efficacy of ciprofloxacin and metronidazole have shown that patients responded to antibiotics, but complete remission was difficult to

Table 2. Treatment strategy of the recent guidelines or reviews

\begin{tabular}{|c|c|c|c|c|c|}
\hline Study & Year & Form & Nation/organization & Classification of treatment & Treatment \\
\hline \multirow[t]{4}{*}{ Schwartz et al. [54] } & 2015 & Statement & United States & Simple without proctitis & Antibiotics+Imm \\
\hline & & & & Simple with proctitis & Antibiotics+Imm+TNF \\
\hline & & & & Rectovaginal & Seton+Antibiotics+Imm+TNF, Flap \\
\hline & & & & Refractory & Fibrin glue, fibrin plug, diversion, proctectomy \\
\hline & & & & Complex & Seton, Flap, fibrin plug, LIFT, diversion, proctectomy \\
\hline \multirow[t]{3}{*}{ Park et al. [56] } & 2017 & Guideline & Korea & Asymptomatic simple & Not require treatment \\
\hline & & & & Symptomatic simple & Antibiotics+seton or fistulotomy \\
\hline & & & & Complex & Seton+TNF (1st \& maintenance) \\
\hline \multirow[t]{2}{*}{ Panés et al. [3] } & 2017 & Review & Spain & Simple without proctitis & Antibiotics+Imm; fail, MSCs+Imm or fistulotomy or LIFT \\
\hline & & & & 1st fail with proctitis & Switch vedolizumab, tacrolimus \\
\hline \multirow[t]{2}{*}{ Kotze et al. [10] } & 2018 & Review & Multination & Mucosal healing at rectum & Fistula healing, maintenance; no healing, add procedure \\
\hline & & & & Active disease at rectum & Optimization of TNF; still active, new biologics \\
\hline \multirow[t]{2}{*}{ Steinhart et al. [22] } & 2019 & Guideline & Toronto Consensus & Uncomplicated & $\begin{array}{l}\text { TNF with or without Imm; symptom response, maintain; } \\
\text { inadequate, surgery }\end{array}$ \\
\hline & & & & Complicated & Seton or abscess drain+TNF with or without Imm \\
\hline
\end{tabular}

Imm, immunomodulators (azathioprine, methotrexate); TNF, anti-tumor necrosis factor agent; Flap, mucosal advancement flap; ASCRS, American Society of Colon and Rectal Surgeon; LIFT, ligation of intersphincteric fistula tract; MSCs, mesenchymal stem cells. 
achieve with antibiotics $[57,58]$.

An old, retrospective, surgical case series on this type of fistula has shown that fistulotomy alone induced remission in $85 \%$ of patients with this type of fistula [61]. Other studies also reported that $62 \%-100 \%$ of patients achieved complete remission after fistulotomy with a mild incontinence rate of 6\%-12\% [62-66]. Ligation of intersphincteric fistula tract (LIFT), first described in 2007, may be also considered for this type of fistula $[67,68]$. The rate of perianal fistula healing following LIFT ranges from $48 \%$ to $67 \%$ depending on the duration of follow-up without reported incontinence [69]. A small case series prospectively evaluated 15 patients with CD undergoing LIFT for transphincteric fistulas and found improvements in the Wexner Perianal Crohn's Disease Activity Index (PCDAI) and McMaster PCDAI from 14.0 to 3.8 and 10.4 to 1.8 , respectively [70]. The rate of perianal fistula healing following EMAF ranges from $33 \%$ to $93 \%$, but incontinence is reported in approximately $10 \%$ of patients, and this proportion may be higher in the presence of scarring due to a prior attempt of fistula repair [71]. Although the evidence was limited and the number of cases was small, fistulotomy or LIFT alone was recommended for the management of this type of perianal fistula (Table 2). Before starting or continuing medical treatment, waiting for symptomatic relief and resolution of skin erythema is required.

\section{Complex perianal fistula in Crohn disease patients}

Complex perianal fistulas are estimated to account for $70 \%$ to $80 \%$ of perianal fistula in CD patients, as defined by the AGA classification [72]. These fistulas have a high location of origin from the fistulous tract, multiple external openings, are associated with pain or fluctuation (abscess), and/or are connected to an adjacent structure (bladder, vagina) [16]. Ultimately, $10 \%$ to $20 \%$ of $\mathrm{CD}$ patients with perianal fistulas require proctectomy or proctocolectomy, with up to $25 \%$ of these patients experiencing poor wound healing or the formation of a perineal sinus as a surgical complication [3]; therefore, careful and strategic management is required for complex perianal fistulas in $\mathrm{CD}$ patients.

Seton procedures are a common practice in the management of perianal fistula in CD patients [73]. Seton procedures are used to drain the fistula and prevent the accumulation of pus, which may lead to recurrent abscesses, and minimize sphincter injuries in an attempt to closure of the fistula tract. Seton procedures involve surgical thread loops passed from the internal to the external opening of the fistula tract and exteriorized through the anorectal canal [74]. In patients about to start biologic therapy, colorectal surgeons aim to provide a fully drained the complex perianal fistula to reduce the risk of abscess formation and to improve the likelihood of success with medical treatment [75]. The recent European Crohn's and Colitis Orgarnisation (ECCO) guideline states that the key surgery of the complex perianal fistula is controlling perianal sepsis by EUA and appropriate seton procedure [76].

Physicians have utilized this function of seton procedures but are aware of the concern that epithelization may occur if the healing timing of perianal fistula is left too long, and this may hinder the response to medical or surgical treatment. Based on the findings of a randomized controlled trial (Treatment of Perianal Fistulas in Crohn's Disease, Seton Versus Anti-TNF Versus Surgical Closure Following Anti-TNF [PISA] study), chronic seton placement should not be recommended as the sole treatment for perianal fistulas in $\mathrm{CD}$ patients $[77,78]$. Although there are no guidelines for the timing of removal, seton drains may be retained in the long-term (months to years) without negative consequences depending on clinical scenario and patient factors, but leaving seton in place may interfere with the wound healing of fistula track itself. A study on the timing of seton removal should be conducted. Cutting seton drains are generally not recommended due to the risk of damage to the sphincter and deformation of the anus [79].

Seton procedures have a low incidence of re-intervention, recurrent abscess formation, and side-branching of the fistulous tract, with preservation of this fistulous tract's patency and cost-effectiveness [80]. The major disadvantages of seton procedures are discomfort and time to achieve stability. The major disadvantage associated with anti-tumor necrosis factor-alpha (anti-TNF- $\alpha$ ) therapy as the sole therapy includes a high re-intervention rate, prolonged maintenance therapy, high recurrence rate, and severe side effects. Therefore, seton procedures and anti-TNF- $\alpha$ therapy should be used concurrently to increase the fistula healing or closure rate. Overall, combined medical and surgical management with drainage, seton procedures, and infliximab therapy has been shown to be superior to either medical or surgical treatment alone $[56,78]$.

\section{Recurrent or persistent perianal fistula in Crohn disease without rectal involvement}

Use of EMAF is a reasonable approach to treating recurrent or persistent perianal fistulas in the absence of proctitis or stenosis [81]. A major advantage of this procedure is that it avoids external wounds that are difficult to heal. In CD patients, the pooled success rate of EMAF is approximately $66 \%$ [40, 82], and a recent meta-analysis observed a $61 \%$ success rate [83]. However, surgeons should be careful about the higher rate $(7.8 \%)$ of fecal incontinence after EMAF, compared with the rate of LIFT (1.6\%) [83]. Patients with a failed initial flap procedure are candidates for a repeat procedure, although failure rates expectedly increase with repeat attempts [84]. Healing rates have improved over time, as patients are treated with biologic therapy, video-assisted anal fistula treatment (VAAFT), and platelet-rich plasma adjuncts [82, 85, 86]. Anal fistula plugs and fibrin glue have both been studied in CD patients with low rate of complete healing, especially for recurrent or persistent perianal fistula in CD patients; therefore, both techniques should be considered carefully when used to resolve this type of perianal fistula [87-89]. A systematic review showed that the pooled success rate of plugs for the recurrent 
perianal fistula was 40\% [90]. Fibrin glue showed a wide range of success rates with limited efficacy [76], rather, fibrin glue is being used in combination with stem cell therapy and reported good results [91].

An area of emerging research is the injection of stem cells into fistula tracts. The phase III randomized controlled ADMIRE-CD (Adipose Derived Mesenchymal Stem Cells for Induction of Remission in Perianal Fistulizing Crohn's Disease) trial found that injection of allogeneic expanded adipose-derived stem cells directly into treatment-refractory complex perianal fistulas of 212 patients with $\mathrm{CD}$ resulted in remission in $51.5 \%$ of patients at 24 weeks and $56.3 \%$ of patients at 52 weeks, compared to a remission rate of $35.6 \%$ at 24 weeks and $38.6 \%$ at 52 weeks with saline placebo [72, 92]. A phase II trial reported that long-term results of autologous adipose-derived stem cell therapy were $75 \%$ complete healing at 24 months [93], and this trial is conducting a phase III clinical study in CD patients with complex and recurrent perianal fistulas. More recently, a phase-I trial studied the application of mesenchymal stem cells-coated fistula plugs into 12 patients with chronic perianal fistulas and showed $83 \%$ complete clinical healing at 6 months [94]. Although there are no studies comparing autologous and allogeneic stem cells for perianal fistula [76], stem cell therapy could be an effective and safe treatment option for perianal fistula in CD (Table 3 [32, 58, 70, 72, 88, 92-107]).

\section{Perianal fistula in Crohn disease patients with horseshoe abscesses}

Deep postanal abscesses comprise less than $15 \%$ of all types of anorectal abscesses [108]. For the treatment of deep postanal abscesses with unilateral or bilateral horseshoe extensions, the modified Hanley procedure is recommended [109]. After a full debridement of any abscesses, a silastic drain may be passed from the posterior incision through the lateral incisions on both affected sides and when present the fistula can be controlled with a draining seton. When the abscess is controlled and the erythematous skin is subsided, the management should be performed according to the management strategy of the complex perianal fistula.

Table 3. Results from the recent prospective studies

\begin{tabular}{|c|c|c|c|c|}
\hline Study & Tx category & Tx type & No. of patients & Main outcome \\
\hline West et al. [95] & Antibiotics & Cipro with infliximab & 24 & $\begin{array}{l}\text { Response: } 73 \% \text { (Cipro) vs. 39\% (placebo) at } 18 \text { wk ( } P=0.12) \text {, PDAl improved } \\
\quad(P=0.008)\end{array}$ \\
\hline Thia et al. [58] & Antibiotics & Antibiotics & 25 & CR: 30\% (Cipro), 0\% (metro), $12.5 \%$ (placebo) at 10 wk \\
\hline Dewint et al. [96] & Antibiotics & Adalimumab with Cipro & 76 & CR: $71 \%$ (Adal. with Cipro) vs. $47 \%$ (Adal. only) at 12 wk; no difference at 24 wk \\
\hline Sciaudone et al. [97] & Biologics & TNF vs. combined & 35 & Combined: longer mean time to relapse $(P<0.05)$ \\
\hline Molendijk et al. [32] & Biologics & Medical and surgical & 232 & CR: $66.7 \%$ (simple) vs. 37\% (complex) \\
\hline Schwandner et al. [98] & AFP & AFP & 16 & Stoma reversal, $75 \%$ vs. $66 \%$ at 9 mo \\
\hline Senéjoux et al. [99] & AFP & AFP & 106 & CR: $31.5 \%$ (plug) vs. $23.1 \%$ (control) at $12 \mathrm{wk}(P=0.19)$ \\
\hline Grimaud et al. [88] & Glue & Fibrin glue & 77 & $\begin{array}{l}\text { CR: } 38 \% \text { (glue) vs. } 16 \% \text { (observation) at } 8 \text { wk }(P=0.04) \text { but not significant in } \\
\text { complex fistula }\end{array}$ \\
\hline Gingold et al. [70] & LIFT & LIFT & 15 & Healing rate: $60 \%$ at $2 \mathrm{mo}$, no incontinence \\
\hline Reinisch et al. [100] & SCA & Spherical carbon adsorbent & 249 & Fistula response: $23.0 \%$ vs. $25.2 \%$ (placebo) $(P=0.22)$ \\
\hline Zawadzki et al. [101] & SCA & Spherical carbon adsorbent & 28 & CR: $35.7 \%$ at 8 wk \\
\hline de la Portilla et al. [102] & Stem cell & Allogeneic MSCs & 24 & $69.2 \%$ reduction in number, $56.3 \%$ closure at 24 wk \\
\hline Molendijk et al. [103] & Stem cell & Allogeneic MSCs & 21 & CR: $85.7 \%\left(3 \times 10^{7}\right)$ vs. $33.3 \%$ (placebo) $(P=0.06)$ \\
\hline Cho et al. [93] & Stem cell & Autologous ASCs & 26 & CR: $75 \%$, modified per-protocol analysis \\
\hline Panés et al. [72] & Stem cell & Allogeneic ASCs & 212 & CR: $51.5 \%$ (ASC) vs. $35.6 \%$ (saline) at 24 wk ( $P=0.021)$ \\
\hline Dietz et al. [94] & Stem cell & MSC-coated matrix plug & 12 & CR: $83 \%$ at 6 mo \\
\hline Panés et al. [92] & Stem cell & Allogeneic ASCs & 212 & CR: $56.3 \%$ (ASC) vs. $38.6 \%$ (saline) at 52 wk $(P=0.01)$ \\
\hline Dozois et al. [104] & Stem cell & MSCs-loaded plug & 15 & CR: 20\%; partial healing, $53.3 \%$ at 6 mo; radiologic improvement, $73.3 \%$ \\
\hline Serrero et al. [105] & Stem cell & ADSVF & 10 & Response/CR: $70 \% / 20 \%$ at 12 wk, $80 \% / 60 \%$ at 48 wk \\
\hline Dige et al. [106] & Stem cell & Autologous adipose tissue & 21 & CR: $57 \%$; ceased secretion of $14 \%$, reduced secretion of $5 \%$ at 6 mo \\
\hline Barnhoorn et al. [107] & Stem cell & Allogeneic BM MSCs & 13 & Magnetic resonance imaging improvement: 67\% after 4 yr \\
\hline
\end{tabular}

Tx, treatment; Cipro, ciprofloxacin; PDAl, perianal disease activity index; CR, complete remission; metro, metronidazole; Adal., adalimumab; TNF, anti-tumor necrosis factor; AFP, anal fistula plug; LIFT, ligation of intersphincteric fistula tract; SCA, spherical carbon adsorbent; MSC, mesenchymal stem cell; ASC, adipose-derived stem cell; ADSVF, adipose-derived stromal vascular fraction; BM, bone marrow. 


\section{Refractory or uncontrolled perianal fistula in Crohn disease (diversion/proctectomy)}

Patients with refractory perianal disease may require temporary fecal diversion or proctectomy. A meta-analysis of 16 studies including 556 patients for refractory perianal CD reported an early response in $63.8 \%$ of patients and low attempts $(34.5 \%)$ and low success rate $(16.6 \%)$ of restoration of bowel continuity after fecal diversion, and finally, $41.6 \%$ of patients who failed temporary diversion required proctectomy [110]. Proctectomy is the last option for refractory or uncontrolled perianal fistula in CD patients that has not responded to both aggressive medical and surgical management. Although rectal involvement is associated with a higher rate of proctectomy compared with rectal sparing $(29 \%-$ $77 \%$ vs. $4 \%-13 \%$ ) [31, 65], rectal involvement alone could not determine proctectomy and fecal diversion might offer an alternative to extensive resection [111]. In cases with concomitant Crohn colitis and perineal disease, proctocolectomy is preferred over rectal preservation due to the high incidence of persistent rectal stump disease when a stump is left in situ [112]. In terms of poor wound healing or a persistent perineal sinus after proctectomy or proctocolectomy, risk factors associated with a persistent sinus are younger patient age, fecal contamination, and extrasphincteric dissection, needed in cases of severe anorectal disease [113]. When deciding on a proctectomy, these results should be fully considered and explained to the patients. The patients who have had perianal fistulas for more than 10 years are likely to be associated with cancer [114], therefore, patients with long-standing refractory perianal fistulas should be monitored carefully for cancer.

\section{SURGEONS' PERSPECTIVES}

Perianal fistulas are generally classified into 2 types in the clinical setting based on the AGA classification; simple and complex. However, in the case of high fistulas, the definition of "high" should be accurately established, e.g. trans-, supra-, and extrasphincteric fistulas. The use of antibiotics is likely to be decided depending on the patients' condition as mentioned in the current review, but studies on the use of antibiotics during the follow-up period or clinical course according to different situations are insufficient. Although the seton procedure is the most widely used and known as one of the most appropriate surgical methods, further research on the appropriate timing of seton removal will be needed. From the point of view of the colorectal surgeon, the timing of referring to medical treatment after surgery is important, and it is necessary to study when the escalation of drug dose or the change of kind of drug should be started after surgery [115]. The timing of outcome assessment varies in each study, from 8 weeks to 12 months after surgery. Therefore, physicians should evaluate the schedule and intervals between testing to determine outcomes.

\section{CONCLUSIONS}

To plan the management of a perianal fistula in CD patients, thorough examination of the perianal fistula and risk evaluation are required. Asymptomatic perianal fistula in $\mathrm{CD}$ patients without rectal involvement do not need interventions. After controlling symptomatic lesions, perianal fistulas should be managed using combined medical and surgical treatment for achieving complete remission. Surgical treatment of a simple, symptomatic perianal fistula without rectal involvement mostly involves fistulotomy with the short-term use of antibiotics and in recent cases, LIFT. Complex perianal fistula treatment should be microinvasive, involving non-cutting seton procedure, followed by medical treatment. For persistent and refractory perianal fistula, use of EMAF, anal fistula plug, fibrin glue, and VAAFT have been used, but the rate of complete remission is not promising. Some stem cell studies for complex, recurrent, and persistent perianal fistula showed good results, but in order to actively introduce stem cell therapy, long-term results and more clinical phase III study results will be required. Diversion or proctectomy is the final stage in the treatment of perianal CD in the patient with severe and long-standing perianal fistulas with malignancy concerns.

\section{CONFLICT OF INTEREST}

No potential conflict of interest relevant to this article was reported.

\section{REFERENCES}

1. Siegmund B, Feakins RM, Barmias G, Ludvig JC, Teixeira FV, Rogler G, et al. Results of the fifth Scientific Workshop of the ECCO (II): pathophysiology of perianal fistulizing disease. J Crohns Colitis 2016;10:377-86.

2. Schwartz DA, Loftus EV Jr, Tremaine WJ, Panaccione R, Harmsen WS, Zinsmeister AR, et al. The natural history of fistulizing Crohn's disease in Olmsted County, Minnesota. Gastroenterology 2002;122:875-80.

3. Panés J, Rimola J. Perianal fistulizing Crohn's disease: pathogenesis, diagnosis and therapy. Nat Rev Gastroenterol Hepatol 2017; 14:652-64.

4. Park SH, Aniwan S, Scott Harmsen W, Tremaine WJ, Lightner $\mathrm{AL}$, Faubion WA, et al. Update on the natural course of fistulizing perianal Crohn's disease in a population-based cohort. Inflamm Bowel Dis 2019;25:1054-60.

5. García-Olmo D, Van Assche G, Tagarro I, Diez MC, Richard MP, Khalid JM, et al. Prevalence of anal fistulas in Europe: systematic literature reviews and population-based database analysis. Adv Ther 2019;36:3503-18.

6. Cheon JH, Kim YS, Ye BD, Lee KM, Kim YH, Kim JS, et al. Crohn's Disease Clinical Network and Cohort (CONNECT) Study: the first step toward nationwide multicenter research of 
Crohn's disease in Korea. Intest Res 2014;12:173-5.

7. Jung YS, Park DI, Ye BD, Cheon JH, Kim YS, Kim YH, et al. Long-term clinical outcomes of urban versus rural environment in Korean patients with Crohn's disease: results from the CONNECT study. J Crohns Colitis 2015;9:246-51.

8. Satsangi J, Silverberg MS, Vermeire S, Colombel JF. The Montreal classification of inflammatory bowel disease: controversies, consensus, and implications. Gut 2006;55:749-53.

9. Louis E, Collard A, Oger AF, Degroote E, Aboul Nasr El Yafi FA, Belaiche J. Behaviour of Crohn's disease according to the Vienna classification: changing pattern over the course of the disease. Gut 2001;49:777-82.

10. Kotze PG, Shen B, Lightner A, Yamamoto T, Spinelli A, Ghosh S, et al. Modern management of perianal fistulas in Crohn's disease: future directions. Gut 2018;67:1181-94.

11. Gecse KB, Bemelman W, Kamm MA, Stoker J, Khanna R, Ng $\mathrm{SC}$, et al. A global consensus on the classification, diagnosis and multidisciplinary treatment of perianal fistulising Crohn's disease. Gut 2014;63:1381-92.

12. Yassin NA, Askari A, Warusavitarne J, Faiz OD, Athanasiou T, Phillips RK, et al. Systematic review: the combined surgical and medical treatment of fistulising perianal Crohn's disease. Aliment Pharmacol Ther 2014;40:741-9.

13. Colombel JF, Sandborn WJ, Reinisch W, Mantzaris GJ, Kornbluth A, Rachmilewitz D, et al. Infliximab, azathioprine, or combination therapy for Crohn's disease. N Engl J Med 2010;362:138395.

14. Michalopoulos A, Papadopoulos V, Tziris N, Apostolidis S. Perianal fistulas. Tech Coloproctol 2010;14(Suppl 1):S15-7.

15. Parks AG, Gordon PH, Hardcastle JD. A classification of fistulain-ano. Br J Surg 1976;63:1-12.

16. Sandborn WJ, Fazio VW, Feagan BG, Hanauer SB. American Gastroenterological Association Clinical Practice Committee. AGA technical review on perianal Crohn's disease. Gastroenterology 2003;125:1508-30.

17. Tozer P, Ng SC, Siddiqui MR, Plamondon S, Burling D, Gupta A, et al. Long-term MRI-guided combined anti-TNF- $\alpha$ and thiopurine therapy for Crohn's perianal fistulas. Inflamm Bowel Dis 2012;18:1825-34.

18. Spencer JA, Ward J, Beckingham IJ, Adams C, Ambrose NS. Dynamic contrast-enhanced MR imaging of perianal fistulas. AJR Am J Roentgenol 1996;167:735-41.

19. Morris J, Spencer JA, Ambrose NS. MR imaging classification of perianal fistulas and its implications for patient management. Radiographics 2000;20:623-37.

20. Jimenez M, Mandava N. Anorectal fistula [updated 2020 Jul 8]. In: StatPearls [Internet]. Treasure Island (FL): StatPearls Publishing; 2020 [cited 2021 Feb 13]. Available from: https://www.ncbi. nlm.nih.gov/books/NBK560657/.

21. Hughes LE. Surgical pathology and management of anorectal Crohn's disease. J R Soc Med 1978;71:644-51.

22. Steinhart AH, Panaccione R, Targownik L, Bressler B, Khanna R,
Marshall JK, et al. Clinical practice guideline for the medical management of perianal fistulizing Crohn's disease: the Toronto Consensus. Inflamm Bowel Dis 2019;25:1-13.

23. Thomassin L, Armengol-Debeir L, Charpentier C, Bridoux V, Koning E, Savoye G, et al. Magnetic resonance imaging may predict deep remission in patients with perianal fistulizing Crohn's disease. World J Gastroenterol 2017;23:4285-92.

24. Tougeron D, Savoye G, Savoye-Collet C, Koning E, Michot F, Lerebours E. Predicting factors of fistula healing and clinical remission after infliximab-based combined therapy for perianal fistulizing Crohn's disease. Dig Dis Sci 2009;54:1746-52.

25. Sebastian S, Black C, Pugliese D, Armuzzi A, Sahnan K, Elkady $\mathrm{SM}$, et al. The role of multimodal treatment in Crohn's disease patients with perianal fistula: a multicentre retrospective cohort study. Aliment Pharmacol Ther 2018;48:941-50.

26. Roumeguère P, Bouchard D, Pigot F, Castinel A, Juguet F, Gaye D, et al. Combined approach with infliximab, surgery, and methotrexate in severe fistulizing anoperineal Crohn's disease: results from a prospective study. Inflamm Bowel Dis 2011;17:69-76.

27. Present DH, Rutgeerts P, Targan S, Hanauer SB, Mayer L, van Hogezand RA, et al. Infliximab for the treatment of fistulas in patients with Crohn's disease. N Engl J Med 1999;340:1398-405.

28. Gecse KB, Sebastian S, Hertogh Gd, Yassin NA, Kotze PG, Reinisch W, et al. Results of the fifth Scientific Workshop of the ECCO [II]: clinical aspects of perianal fistulising Crohn's disease: the unmet needs. J Crohns Colitis 2016;10:758-65.

29. Makowiec F, Jehle EC, Starlinger M. Clinical course of perianal fistulas in Crohn's disease. Gut 1995;37:696-701.

30. Hurst RD, Molinari M, Chung TP, Rubin M, Michelassi F. Prospective study of the features, indications, and surgical treatment in 513 consecutive patients affected by Crohn's disease. Surgery; $122: 661-8$.

31. Bell SJ, Williams AB, Wiesel P, Wilkinson K, Cohen RC, Kamm MA. The clinical course of fistulating Crohn's disease. Aliment Pharmacol Ther 2003;17:1145-51.

32. Molendijk I, Nuij VJ, van der Meulen-de Jong AE, van der Woude CJ. Disappointing durable remission rates in complex Crohn's disease fistula. Inflamm Bowel Dis 2014;20:2022-8.

33. Castaño-Milla C, Chaparro M, Saro C, Barreiro-de Acosta M, García-Albert AM, Bujanda L, et al. Effectiveness of adalimumab in perianal fistulas in Crohn's disease patients naive to anti-TNF therapy. J Clin Gastroenterol 2015;49:34-40.

34. Mei Z, Wang Q, Zhang Y, Liu P, Ge M, Du P, et al. Risk factors for recurrence after anal fistula surgery: a meta-analysis. Int J Surg 2019;69:153-64.

35. Zimmerman DD, Delemarre JB, Gosselink MP, Hop WC, Briel JW, Schouten WR. Smoking affects the outcome of transanal mucosal advancement flap repair of trans-sphincteric fistulas. $\mathrm{Br}$ J Surg 2003;90:351-4.

36. Devaraj B, Khabassi S, Cosman BC. Recent smoking is a risk factor for anal abscess and fistula. Dis Colon Rectum 2011;54:6815 . 
37. Haennig A, Staumont G, Lepage B, Faure P, Alric L, Buscail L, et al. The results of seton drainage combined with anti-TNFa therapy for anal fistula in Crohn's disease. Colorectal Dis 2015;17: 311-9.

38. Schnitzler F, Friedrich M, Wolf C, Stallhofer J, Angelberger M, Diegelmann J, et al. The NOD2 single nucleotide polymorphism rs72796353 (IVS4+10 A $>$ C) is a predictor for perianal fistulas in patients with Crohn's disease in the absence of other NOD2 mutations. PLoS One 2015;10:e0116044.

39. Angelberger S, Reinisch W, Dejaco C, Miehsler W, Waldhoer T, Wehkamp J, et al. NOD2/CARD15 gene variants are linked to failure of antibiotic treatment in perianal fistulating Crohn's disease. Am J Gastroenterol 2008;103:1197-202.

40. El-Gazzaz G, Hull T, Church JM. Biological immunomodulators improve the healing rate in surgically treated perianal Crohn's fistulas. Colorectal Dis 2012;14:1217-23.

41. Abbas MA, Jackson CH, Haigh PI. Predictors of outcome for anal fistula surgery. Arch Surg 2011;146:1011-6.

42. Jordán J, Roig JV, García-Armengol J, García-Granero E, Solana A, Lledó S. Risk factors for recurrence and incontinence after anal fistula surgery. Colorectal Dis 2010;12:254-60.

43. van Onkelen RS, Gosselink MP, Thijsse S, Schouten WR. Predictors of outcome after transanal advancement flap repair for high transsphincteric fistulas. Dis Colon Rectum 2014;57:1007-11.

44. Schulze B, Ho YH. Management of complex anorectal fistulas with seton drainage plus partial fistulotomy and subsequent ligation of intersphincteric fistula tract (LIFT). Tech Coloproctol 2015;19:89-95.

45. Poon CM, Ng DC, Ho-Yin MC, Li RS, Leong HT. Recurrence pattern of fistula-in-ano in a Chinese population. J Gastrointestin Liver Dis 2008;17:53-7.

46. Garcia-Aguilar J, Belmonte C, Wong WD, Goldberg SM, Madoff RD. Anal fistula surgery: factors associated with recurrence and incontinence. Dis Colon Rectum 1996;39:723-9.

47. Ding JH, Bi LX, Zhao K, Feng YY, Zhu J, Zhang B, et al. Impact of three-dimensional endoanal ultrasound on the outcome of anal fistula surgery: a prospective cohort study. Colorectal Dis 2015;17:1104-12.

48. van Koperen PJ, Wind J, Bemelman WA, Bakx R, Reitsma JB, Slors JF. Long-term functional outcome and risk factors for recurrence after surgical treatment for low and high perianal fistulas of cryptoglandular origin. Dis Colon Rectum 2008;51:147581.

49. Galandiuk S, Kimberling J, Al-Mishlab TG, Stromberg AJ. Perianal Crohn disease: predictors of need for permanent diversion. Ann Surg 2005;241:796-802.

50. Gu J, Valente MA, Remzi FH, Stocchi L. Factors affecting the fate of faecal diversion in patients with perianal Crohn's disease. Colorectal Dis 2015;17:66-72.

51. Löffler T, Welsch T, Mühl S, Hinz U, Schmidt J, Kienle P. Longterm success rate after surgical treatment of anorectal and rectovaginal fistulas in Crohn's disease. Int J Colorectal Dis 2009;24:
521-6.

52. Sauk J, Nguyen D, Yajnik V, Khalili H, Konijeti G, Hodin R, et al. Natural history of perianal Crohn's disease after fecal diversion. Inflamm Bowel Dis 2014;20:2260-5.

53. Yamamoto T, Allan RN, Keighley MR. Effect of fecal diversion alone on perianal Crohn's disease. World J Surg 2000;24:1258-63.

54. Schwartz DA, Ghazi LJ, Regueiro M, Fichera A, Zoccali M, Ong $\mathrm{EM}$, et al. Guidelines for the multidisciplinary management of Crohn's perianal fistulas: summary statement. Inflamm Bowel Dis 2015;21:723-30.

55. Vogel JD, Johnson EK, Morris AM, Paquette IM, Saclarides TJ, Feingold DL, et al. Clinical practice guideline for the management of anorectal abscess, fistula-in-ano, and rectovaginal fistula. Dis Colon Rectum 2016;59:1117-33.

56. Park JJ, Yang SK, Ye BD, Kim JW, Park DI, Yoon H, et al. Second Korean guidelines for the management of Crohn's disease. Korean J Gastroenterol 2017;69:29-54.

57. Bernstein LH, Frank MS, Brandt LJ, Boley SJ. Healing of perineal Crohn's disease with metronidazole. Gastroenterology 1980;79: 357-65.

58. Thia KT, Mahadevan U, Feagan BG, Wong C, Cockeram A, Bitton A, et al. Ciprofloxacin or metronidazole for the treatment of perianal fistulas in patients with Crohn's disease: a randomized, double-blind, placebo-controlled pilot study. Inflamm Bowel Dis 2009;15:17-24.

59. Beck DE, Roberts PL, Rombeau JL, Stamos MJ, Wexner SD. Benign anorectal: rectovaginal fistulas. In: Wexner SD, Stamos MJ, Rombeau JL, Roberts PL, Beck DE, editors. The ASCRS manual of colon and rectal surgery. New York (NY): Springer; 2009.

60. Gomollón F, Dignass A, Annese V, Tilg H, Van Assche G, Lindsay JO, et al. 3rd European evidence-based consensus on the diagnosis and management of Crohn's disease 2016: part 1: diagnosis and medical management. J Crohns Colitis 2017;11:3-25.

61. Levien DH, Surrell J, Mazier WP. Surgical treatment of anorectal fistula in patients with Crohn's disease. Surg Gynecol Obstet 1989;169:133-6.

62. McKee RF, Keenan RA. Perianal Crohn's disease: is it all bad news? Dis Colon Rectum 1996;39:136-42.

63. Williams JG, Rothenberger DA, Nemer FD, Goldberg SM. Fistula-in-ano in Crohn's disease: results of aggressive surgical treatment. Dis Colon Rectum 1991;34:378-84.

64. Scott HJ, Northover JM. Evaluation of surgery for perianal Crohn's fistulas. Dis Colon Rectum 1996;39:1039-43.

65. Michelassi F, Melis M, Rubin M, Hurst RD. Surgical treatment of anorectal complications in Crohn's disease. Surgery 2000;128: 597-603.

66. van Koperen PJ, Safiruddin F, Bemelman WA, Slors JF. Outcome of surgical treatment for fistula in ano in Crohn's disease. Br J Surg 2009;96:675-9.

67. Rojanasakul A, Pattanaarun J, Sahakitrungruang C, Tantiphlachiva $\mathrm{K}$. Total anal sphincter saving technique for fistula-in-ano; the ligation of intersphincteric fistula tract. J Med Assoc Thai 
2007;90:581-6.

68. Mahmoud NN, Halwani Y, Montbrun S, Shah PM, Hedrick TL, Rashid F, et al. Current management of perianal Crohn's disease. Curr Probl Surg 2017;54:262-98.

69. Kamiński JP, Zaghiyan K, Fleshner P. Increasing experience of ligation of the intersphincteric fistula tract for patients with Crohn's disease: what have we learned? Colorectal Dis 2017;19: 750-5.

70. Gingold DS, Murrell ZA, Fleshner PR. A prospective evaluation of the ligation of the intersphincteric tract procedure for complex anal fistula in patients with Crohn's disease. Ann Surg 2014; 260:1057-61.

71. Soltani A, Kaiser AM. Endorectal advancement flap for cryptoglandular or Crohn's fistula-in-ano. Dis Colon Rectum 2010;53: 486-95.

72. Panés J, García-Olmo D, Van Assche G, Colombel JF, Reinisch W, Baumgart DC, et al. Expanded allogeneic adipose-derived mesenchymal stem cells (Cx601) for complex perianal fistulas in Crohn's disease: a phase 3 randomised, double-blind controlled trial. Lancet 2016;388:1281-90.

73. Lee MJ, Heywood N, Sagar PM, Brown SR, Fearnhead NS; pCD Collaborators. Surgical management of fistulating perianal Crohn's disease: a UK survey. Colorectal Dis 2017;19:266-73.

74. Jeon M, Song K, Koo J, Kim S. Evaluation of a seton procedure combined with infliximab therapy (early vs. late) in perianal fistula with Crohn disease. Ann Coloproctol 2019;35:249-53.

75. Regueiro M, Mardini H. Treatment of perianal fistulizing Crohn's disease with infliximab alone or as an adjunct to exam under anesthesia with seton placement. Inflamm Bowel Dis 2003;9:98-103.

76. Adamina M, Bonovas S, Raine T, Spinelli A, Warusavitarne J, Armuzzi A, et al. ECCO guidelines on therapeutics in Crohn's disease: surgical treatment. J Crohns Colitis 2020;14:155-68.

77. de Groof EJ, Buskens CJ, Ponsioen CY, Dijkgraaf MG, D’Haens GR, Srivastava N, et al. Multimodal treatment of perianal fistulas in Crohn's disease: seton versus anti-TNF versus advancement plasty (PISA): study protocol for a randomized controlled trial. Trials 2015;16:366.

78. Wasmann KA, de Groof EJ, Stellingwerf ME, D'Haens GR, Ponsioen CY, Gecse KB, et al. Treatment of perianal fistulas in Crohn's disease, seton versus anti-TNF versus surgical closure following anti-TNF [PISA]: a randomised controlled trial. J Crohns Colitis 2020;14:1049-56.

79. Thornton M, Solomon MJ. Long-term indwelling seton for complex anal fistulas in Crohn's disease. Dis Colon Rectum 2005;48: 459-63.

80. Feroz SH, Ahmed A, Muralidharan A, Thirunavukarasu P. Comparison of the efficacy of the various treatment modalities in the management of perianal Crohn's fistula: a review. Cureus 2020; 12:e11882.

81. Sordo-Mejia R, Gaertner WB. Multidisciplinary and evidencebased management of fistulizing perianal Crohn's disease. World
J Gastrointest Pathophysiol 2014;5:239-51.

82. Rozalén V, Parés D, Sanchez E, Troya J, Vela S, Pacha MÁ, et al. Advancement flap technique for anal fistula in patients with Crohn's disease: a systematic review of the literature. Cir Esp 2017;95:558-65.

83. Stellingwerf ME, van Praag EM, Tozer PJ, Bemelman WA, Buskens CJ. Systematic review and meta-analysis of endorectal advancement flap and ligation of the intersphincteric fistula tract for cryptoglandular and Crohn's high perianal fistulas. BJS Open 2019;3:231-41.

84. Nielsen OH, Rogler G, Hahnloser D, Thomsen OØ. Diagnosis and management of fistulizing Crohn's disease. Nat Clin Pract Gastroenterol Hepatol 2009;6:92-106.

85. Schwandner O. Video-assisted anal fistula treatment (VAAFT) combined with advancement flap repair in Crohn's disease. Tech Coloproctol 2013;17:221-5.

86. Göttgens KW, Smeets RR, Stassen LP, Beets GL, Pierik M, Breukink SO. Treatment of Crohn's disease-related high perianal fistulas combining the mucosa advancement flap with plateletrich plasma: a pilot study. Tech Coloproctol 2015;19:455-9.

87. Hjortrup A, Moesgaard F, Kjaergård J. Fibrin adhesive in the treatment of perineal fistulas. Dis Colon Rectum 1991;34:752-4.

88. Grimaud JC, Munoz-Bongrand N, Siproudhis L, Abramowitz L, Sénéjoux A, Vitton V, et al. Fibrin glue is effective healing perianal fistulas in patients with Crohn's disease. Gastroenterology 2010;138:2275-81.

89. Geltzeiler CB, Wieghard N, Tsikitis VL. Recent developments in the surgical management of perianal fistula for Crohn's disease. Ann Gastroenterol 2014;27:320-30.

90. Nasseri Y, Cassella L, Berns M, Zaghiyan K, Cohen J. The anal fistula plug in Crohn's disease patients with fistula-in-ano: a systematic review. Colorectal Dis 2016;18:351-6.

91. Al-Maawali AK, Nguyen P, Phang PT. Modern treatments and stem cell therapies for perianal Crohn's fistulas. Can J Gastroenterol Hepatol 2016;2016:1651570.

92. Panés J, García-Olmo D, Van Assche G, Colombel JF, Reinisch W, Baumgart DC, et al. Long-term efficacy and safety of stem cell therapy (Cx601) for complex perianal fistulas in patients with Crohn's disease. Gastroenterology 2018;154:1334-42.

93. Cho YB, Park KJ, Yoon SN, Song KH, Kim DS, Jung SH, et al. Long-term results of adipose-derived stem cell therapy for the treatment of Crohn's fistula. Stem Cells Transl Med 2015;4:5327.

94. Dietz AB, Dozois EJ, Fletcher JG, Butler GW, Radel D, Lightner $\mathrm{AL}$, et al. Autologous mesenchymal stem cells, applied in a bioabsorbable matrix, for treatment of perianal fistulas in patients with Crohn's disease. Gastroenterology 2017;153:59-62.

95. West RL, van der Woude CJ, Hansen BE, Felt-Bersma RJ, van Tilburg AJ, Drapers JA, et al. Clinical and endosonographic effect of ciprofloxacin on the treatment of perianal fistulae in Crohn's disease with infliximab: a double-blind placebo-controlled study. Aliment Pharmacol Ther 2004;20:1329-36. 
96. Dewint P, Hansen BE, Verhey E, Oldenburg B, Hommes DW, Pierik M, et al. Adalimumab combined with ciprofloxacin is superior to adalimumab monotherapy in perianal fistula closure in Crohn's disease: a randomised, double-blind, placebo controlled trial (ADAFI). Gut 2014;63:292-9.

97. Sciaudone G, Di Stazio C, Limongelli P, Guadagni I, Pellino G, Riegler G, et al. Treatment of complex perianal fistulas in Crohn disease: infliximab, surgery or combined approach. Can J Surg 2010;53:299-304.

98. Schwandner O, Fuerst A. Preliminary results on efficacy in closure of transsphincteric and rectovaginal fistulas associated with Crohn's disease using new biomaterials. Surg Innov 2009;16:1628.

99. Senéjoux A, Siproudhis L, Abramowitz L, Munoz-Bongrand N, Desseaux K, Bouguen G, et al. Fistula plug in fistulising ano-perineal Crohn's disease: a randomised controlled trial. J Crohns Colitis 2016;10:141-8.

100. Reinisch W, Travis S, Hanauer S, Wang H, Shara N, Harris MS. AST-120 (spherical carbon adsorbent) in the treatment of perianal fistulae in mild-to-moderate Crohn's disease: FHAST-1, a phase 3, multicenter, placebo-controlled study. Inflamm Bowel Dis 2014;20:872-81.

101. Zawadzki A, Johnson LB, Bohe M, Johansson C, Ekelund M, Nielsen $\mathrm{OH}$. An open prospective study evaluating efficacy and safety of a new medical device for rectal application of activated carbon in the treatment of chronic, uncomplicated perianal fistulas. Int J Colorectal Dis 2017;32:509-12.

102. de la Portilla F, Alba F, García-Olmo D, Herrerías JM, González FX, Galindo A. Expanded allogeneic adipose-derived stem cells (eASCs) for the treatment of complex perianal fistula in Crohn's disease: results from a multicenter phase I/IIa clinical trial. Int J Colorectal Dis 2013;28:313-23.

103. Molendijk I, Bonsing BA, Roelofs H, Peeters KC, Wasser MN, Dijkstra G, et al. Allogeneic bone marrow-derived mesenchymal stromal cells promote healing of refractory perianal fistulas in patients with Crohn's disease. Gastroenterology 2015;149:91827.

104. Dozois EJ, Lightner AL, Mathis KL, Chua HK, Kelley SR, Fletcher JG, et al. Early results of a phase I trial using an adipose-derived mesenchymal stem cell-coated fistula plug for the treatment of transsphincteric cryptoglandular fistulas. Dis Colon Rectum 2019;62:615-22.
105. Serrero M, Grimaud F, Philandrianos C, Visée C, Sabatier F, Grimaud JC. Long-term safety and efficacy of local microinjection combining autologous microfat and adipose-derived stromal vascular fraction for the treatment of refractory perianal fistula in Crohn's disease. Gastroenterology 2019;156:2335-7.

106. Dige A, Hougaard HT, Agnholt J, Pedersen BG, Tencerova M, Kassem M, et al. Efficacy of injection of freshly collected autologous adipose tissue into perianal fistulas in patients with Crohn's disease. Gastroenterology 2019;156:2208-16.

107. Barnhoorn MC, Wasser MN, Roelofs H, Maljaars PW, Molendijk I, Bonsing BA, et al. Long-term evaluation of allogeneic bone marrow-derived mesenchymal stromal cell therapy for Crohn's disease perianal fistulas. J Crohns Colitis 2020;14:64-70.108.

Hamilton $\mathrm{CH}$. Anorectal problems: the deep postanal space: surgical significance in horseshoe fistula and abscess. Dis Colon Rectum 1975;18:642-5.

108. Hamilton $\mathrm{CH}$. Anorectal problems: the deep postanal space: surgical significance in horseshoe fistula and abscess. Dis Colon Rectum 1975;18:642-5.

109. Browder LK, Sweet S, Kaiser AM. Modified Hanley procedure for management of complex horseshoe fistulae. Tech Coloproctol 2009;13:301-6.

110. Singh S, Ding NS, Mathis KL, Dulai PS, Farrell AM, Pemberton $\mathrm{JH}$, et al. Systematic review with meta-analysis: faecal diversion for management of perianal Crohn's disease. Aliment Pharmacol Ther 2015;42:783-92.

111. Hong MK, Craig Lynch A, Bell S, Woods RJ, Keck JO, Johnston MJ, et al. Faecal diversion in the management of perianal Crohn's disease. Colorectal Dis 2011;13:171-6.

112. Guillem JG, Roberts PL, Murray JJ, Coller JA, Veidenheimer MC, Schoetz DJ Jr. Factors predictive of persistent or recurrent Crohn's disease in excluded rectal segments. Dis Colon Rectum 1992;35:768-72.

113. Yamamoto T, Bain IM, Allan RN, Keighley MR. Persistent perineal sinus after proctocolectomy for Crohn's disease. Dis Colon Rectum 1999;42:96-101.

114. Iesalnieks I, Gaertner WB, Glass H, Strauch U, Hipp M, Agha A, et al. Fistula-associated anal adenocarcinoma in Crohn's disease. Inflamm Bowel Dis 2010;16:1643-8.

115. Lee JL. Factors affecting surgical treatment with infliximab therapy in perianal fistula with Crohn disease. Ann Coloproctol 2019;35:225-6. 